\title{
Euxinic Ocean during the Late Devonian Mass Extinction Inferred from Organic Compounds
}

\author{
Susumu Yatsu, Kunio Kaiho*, Masahiro Oba \\ Graduate School of Science, Tohoku University, Aoba-ku, Sendai 980-8578, Japan \\ $\mathbf{Z} \mathbf{Q}$ Chen \\ School of Earth \& Environment, The University of Western Australia, 35 Stirling Highway, \\ Crawley, WA 6009, Australia \\ Jean-Georges Casier \\ Department of Paleontology, Belgian Royal Institute of Natural Sciences, Vautier Street, 29 B-1000, \\ Brussels, Belgium \\ James D Wright \\ Department of Geological Sciences, Rutgers University, 610 Taylor Road, Piscataway, NJ 08854, USA
}

There were five mass extinctions of Earth life during the past 500 million years. The second crisis of the "big five" mass extinctions occurred near the Frasnian/Famennian (F/F) boundary in the Late Devonian. This extinction impacted mainly oceanic regime and resulted in $21 \%$ of families and $50 \%$ of genera among oceanic life being wiped out (Sepkoski, 1986). In particular, brachiopods, trilobites, conodonts, tabulate corals, and stromatoporoids have been severely affected and suffered high extinction rates (McGhee, 1996, 1989; Stanley, 1987). Previously, anoxic sea-water condition was considered as the candidate responsible for the $\mathrm{F} / \mathrm{F}$ mass extinction simply because of the widespread black shale near the boundary worldwide (House, 1985). Both stable carbon and sulfur isotopic signals and trace metal element features indicate that the $\mathrm{F} / \mathrm{F}$ mass extinction was probably caused by the development of oceanic anoxia (Riquier et al., 2006; Joachimski et al., 2001). However, little has

\footnotetext{
*Corresponding author: kaiho@m.tains.tohoku.ac.jp

(C) China University of Geosciences and Springer-Verlag Berlin Heidelberg 2010
}

Manuscript received December 22, 2009.

Manuscript accepted March 11, 2010. been published on organic geochemical signals across the F/F mass extinction interval. Thus, the purpose of this study is to examine oceanic redox condition spanning the F/F boundary based on organic geochemical analysis incorporating with stable carbon isotope ratio and bioturbation levels from two geographically apart localities, Belgium and China, respectively.

A positive shift of $\delta^{13} \mathrm{C}_{\text {carb }}$ across the $\mathrm{F} / \mathrm{F}$ boundary and high values of $\delta^{13} \mathrm{C}_{\text {carb }}$ in the lower Famennian strata are detected at the F/F boundary sections in Belgium and China, respectively. Contents of organic matter components dibenzothiophenes and 2,3,6- trimethylarylisoprenoids show peaks near the $\mathrm{F} / \mathrm{F}$ boundary at these two studied sections. High values of $\delta^{13} \mathrm{C}_{\mathrm{carb}}$, dibenzothiophenes and 2,3,6- trimethylarylisoprenoids detected from these two geographically apart sections indicate a global spread event of anoxic or euxinic seawater, which should account for the F/F biotic crisis.

\section{REFERENCES CITED}

House, M. R., 1985. Correlation of Mid-Palaeozoic Ammonoid Evolutionary Events with Global Sedimentary Perturbation. Nature, 213: 17-22

Joachimski, M. M., Ostertag-Henning, C., Pancost, R. D., et al., 2001. Water Column Anoxia, Enhanced Productivity and 
Concomitant Changes in $\delta^{13} \mathrm{C}$ and $\delta^{34} \mathrm{~S}$ across the FrasnianFamennian Boundary (Kowala-Holy Cross Mountains/ Poland). Chemical Geology, 175: 109-131

McGhee, G. R. Jr., 1989. Chapter 7. The Frasnian-Famennian Event. In: Donovan, S. K., ed., Mass Extinctions. Process and Evidence. Belhaven Press, London. 133-151

McGhee, G. R. Jr., 1996. The Late Devonian Mass Extinction. The Frasnian/Famennian Crisis. Columbia University Press, N.Y.. 303

Riquier, L., Tribovillard, N., Averbuch, O., et al., 2006. The Late
Frasnian Kellwasser Horizons of the Harz Mountains (Germany): Two Oxygen-Deficient Periods Resulting from Different Mechanisms. Chemical Geology, 233(1-2): $137-155$

Sepkoski, J. J. Jr., 1986. Phanerozoic Overview of Mass Extinction. In: Raup, D. M., Jablonski, D., eds., Patterns and Process in the History of Life. Springer-Verlag, Berlin. 277-295

Stanley, S. M., 1987. Extinction. Scientific American Library 2. Freeman, W. H., N.Y. 
Reproduced with permission of the copyright owner. Further reproduction prohibited without permission. 